\title{
Gender inequality in Australia's tax-transfer system
}

\author{
Miranda Stewart
}

During the 2016 Australian federal election, leaders on both sides of politics sought the 'women's vote'. Prime Minister-elect Malcolm Turnbull for the Liberal-National Coalition Party (LNP) declared himself a feminist, affirming equal opportunity for women and acknowledging that 'women hold up half the sky' (Grattan 2016). Opposition Leader Bill Shorten, of the Australian Labor Party (ALP), said on the eve of the election campaign that a Labor Government would champion 'the march of women to equality' (Shorten 2016). ${ }^{1}$ Yet, in spite of these political commitments, there remain significant tensions and contradictions in core federal economic and fiscal policy affecting women and gender equality.

This volume focuses on gender inequality in two of Australia's main federal policy regimes: the tax system and the welfare or social security ('transfer') system, which together can be described as the tax-transfer system. The expert contributors to this volume from law, economics and social science backgrounds present novel theoretical and empirical research to deepen our understanding of the challenge of gender inequality in taxation, social security, child care, education, savings and retirement policy.

1 The politics and tensions on gender in the 2016 election are explored in more detail in Williams and Sawer (forthcoming). 
The 2016 political commitments to gender equality by both sides of politics were not made in a vacuum. They built on some important, but incomplete, policy developments in the previous decade, which have been positive for gender equality. Many of these originated in the Rudd Labor Government of 2007, but have continued under subsequent LNP governments.

Financial support for child care in Australia has gradually expanded under governments of both stripes, and Australia has boosted the rate of four-year-olds in early childhood education to 85 per cent as a result of National Partnership Agreements commencing under the Rudd Labor Government in 2008 (Department of Education and Training 2017). In the 2017-18 Budget, the federal government extended this partnership funding for one year, to allow all four-year-old children to access 15 hours per week of kindergarten, but the future of this program remains uncertain. The Turnbull LNP Government enacted in 2016 a significantly expanded, although still means tested, child care subsidy to commence in 2018. The government acknowledges the need for improved child care as a necessary step in achieving increased women's workforce participation, which is an explicit government policy (DPMC 2017).

In 2011, the Rudd Labor Government introduced Australia's first paid parental leave (PPL) scheme. The subsequent LNP Government under Prime Minister Abbott appeared to support making this scheme more generous, although this was to be at the expense of other parts of the social security and welfare budget. After protracted and ultimately unsuccessful negotiations to cut social security expenditure following the 2014 budget (Leslie 2014), the PPL scheme has survived to date as enacted in 2011.

There is increased attention being paid to the gender pay gap since the Labor Government under Julia Gillard, Australia's first and only female prime minister, re-established the Workplace Gender Equality Agency (WGEA) in 2012 as a statutory federal agency charged with promoting and improving gender equality in Australian workplaces. WGEA had its origins in the Affirmative Action Agency, established under the Affirmative Action (Equal Opportunity for Women) Act 1986 legislated by the Hawke Labor Government. WGEA has collected and published credible data over the past few years, demonstrating a persistent gender pay gap ranging from 15 per cent to more than 20 per cent (WGEA 2016). ${ }^{2}$

2 The reporting requirements of the Workplace Gender Equality Agency (WGEA) were reduced in 2015 as part of the government's 'red tape reduction strategy' (Harris Rimmer and Sawer 2016). 
There is bipartisan support for gender equality in other areas. Prime Minister Gillard launched, with support from all state and territory governments, the National Plan to Reduce Violence against Women and their Children 2010-2022. The LNP Government has continued to implement it, developing the Third Action Plan 2016-2019. ${ }^{3}$ In 2013, the Abbott LNP Government returned the Office for Women to the Department of Prime Minister and Cabinet, a move welcomed by women's groups. There has also been vocal support for increased representation of women in executive and leadership roles, although progress is slow and affirmative action and quotas have not been adopted. In the area of retirement and savings policy, there has been substantial public debate about women's disadvantage but little policy change. A recent bipartisan Senate report identified and criticised the significant imbalance in women's retirement savings in the superannuation system under the heading 'a husband is not a retirement plan' (Senate Economic References Committee 2016).

The growing policy work and political debate on gender inequality is heartening, but there remain significant gender gaps in work, care, education, employment and retirement in Australia. Some of these gender gaps are summarised in Table 1.1, and are discussed further below.

Table 1.1: Australian gender gaps at a glance, 2017

\begin{tabular}{|l|c|c|}
\hline & Men & Women \\
\hline Workforce participation & $70 \%$ & $59 \%$ \\
\hline Employed part-time & $17 \%$ & $46 \%$ \\
\hline Employed part-time with child <5 & $8 \%$ & $62 \%$ \\
\hline Average full-time weekly wage & $100 \%$ & $84 \%$ \\
\hline $\begin{array}{l}\text { Without paid leave entitlement and with } \\
\text { dependant children }\end{array}$ & $10 \%$ & $20 \%$ \\
\hline Average superannuation & $100 \%$ & $47 \%$ \\
\hline Year 12 (by age 20-24) & $86 \%$ & $90 \%$ \\
\hline Bachelor's degree (by age 25-29) & $30 \%$ & $40 \%$ \\
\hline Unpaid care work & $36 \%$ & $64 \%$ \\
\hline Unpaid housework & 6.2 hours & 18.7 hours \\
\hline Representation in parliaments & $68 \%$ & $32 \%$ \\
\hline
\end{tabular}

Source: ABS (2016); Baird (2017).

3 See Department of Social Services, plan4womenssafety.dss.gov.au/ (accessed 3 June 2017). 
Part 1 of this volume presents three theoretical and global frameworks for analysing gender inequality in the fiscal state: an international and comparative perspective; an economic analysis of fiscal sustainability; and a human rights framework for gender equality in fiscal policy. The focus turns in Part 2 to the central issue of women's economic security, work and care in market and household economies. Contributors address the intersection of tax, social security, child care and parental leave policies to support women's paid work; how Australia recognises and rewards unpaid care work for the wellbeing of women and children; and new empirical research on how women and men balance paid work and child care time. Part 3 turns to the development of human capital, investment and saving of women, including new research on the economic returns to higher education for women and men and Australia's higher education financing scheme; the position of women at the top of the income distribution; and retirement and age pension policy for adequacy of women's incomes in old age. In Part 4, the concluding chapter returns to the pathways and processes to achieve gender equality in the tax-transfer system.

\section{Building on a feminist tradition of fiscal policy and research}

Australian feminists as researchers, government officials, activists and (more recently) politicians, have engaged passionately in debating and changing tax and transfer systems for decades. The second wave of feminism in Australia was not just about sexism but also about the fiscal state. In the 1970s, women were significantly impoverished relative to men by a large gender pay gap and a sex-segregated labour market, more part-time than fulltime work, unequal child care and heavy non-market work responsibilities. Despite improvements, many of these challenges continue today.

The 1970s saw the introduction of universal family allowances among other broad-based policies, but this faced a challenge of delivery in an increasingly fiscally constrained environment during the 1980s. Pioneering feminist researchers including Edwards (1981), Keens and Cass (1982), Baldock and Cass (1983), and Shaver (1989) showed that the structure of income tax rates, allowances, credits and concessions ('fiscal welfare'), the 'social welfare' system and 'occupational' welfare including work-related benefits such as superannuation, all produced significantly unequal gender and class effects in Australia, as in other countries. They also showed that assumptions of equal sharing of income inside the family and household were frequently wrong (Edwards 1981). 
During the 1980s, means testing of family benefits was introduced based on couple income, as was already the case for other welfare payments. Proposals to extend the age pension to be universal (as it is in New Zealand) were not pursued. Feminist political and lobbying organisations, especially the Women's Electoral Lobby (WEL), were an active force engaging with federal policymakers about the budget, seeking to mitigate or counter these trends. They built on broader intersecting analyses of laws affecting gender inequality, including tax, welfare, labour, child support and family law, as explained by Graycar and Morgan (1990). Reforms on which feminist scholars and policymakers engaged, with some victories and some losses, included Jobs, Education and Training for sole parents, child support, the National Housing Strategy, Austudy and the Higher Education Contribution Scheme (HECS). In this active reform context, the 1980s saw senior policymakers such as Meredith Edwards undertake 'a femocrat's journey into attempting to ensure that policies on which I gave advice were consistent with these principles: taking account of work incentives, valuing unpaid work in the home and also the distribution of income within the family. ${ }^{4}$

At this time, feminist scholarship on tax policy was just beginning to develop. The ground-breaking research of Patricia Apps (1981), was important in 'jostling and disturbing' the status quo of tax policy, which failed to recognise substantive unequal outcomes for women and men (Pugh 1983). Apps developed economic theories of optimal taxation and of the family to model and explain the care-work exchange in the household and the differential tax-transfer treatment of care inside and outside the family. This research demonstrated for femocrats working in government that it was both inefficient and inequitable for the tax system to subsidise spouse dependency given that the real income of the taxpaying spouse is augmented by the unpaid domestic activities of the other spouse. The teaching by Apps in public finance at the University of Sydney in the early 1990s informed this author and many others of the unequal economic effects of the tax-transfer system.

Another pioneering scholar on tax and gender was Judith Grbich who identified the role of the tax system in facilitating the accumulation of private wealth under the control of men, including through income splitting and the use of controlled entities such as discretionary trusts (Grbich 1987).

4 Presentation at ASSA Workshop on Gender Inequality in the Tax and Transfer System, 4-5 November 2015, The Australian National University. 
In a different vein, a ground-breaking approach to tax-transfer modelling was led by Ann Harding, who brought this approach to Australia after working with Tony Atkinson at the London School of Economics. Harding worked with the Department of Social Security to establish the National Centre for Social and Economic Modelling (NATSEM) at the University of Canberra in 1993. This modelling enabled a detailed understanding of the distributional impact of the tax-transfer system and helped to demonstrate the effect on women and the fiscal cost of tax and welfare reform.

This scholarly and policy work brought a gender lens to major Australian reports on the tax system (Asprey 1975) and on poverty (Henderson 1975). Bettina Cass led the social security system review for the federal government (1985-88), producing numerous reports on the effects of the system. Also influential was substantial work on gender in the welfare state in the United Kingdom by, among others, Ruth Lister (1992). Across the Atlantic, during the late 1980s, Canadian feminist researchers, working through a series of governmental commissions of inquiry produced some of the first policy reports examining gender and tax policy. Reports included the first comprehensive gender analysis of a country's tax system by tax scholar, Kathleen Lahey (Lahey and Eaton 1988), the author of Chapter 2 in this volume. ${ }^{5}$ Studies by the Canadian Advisory Council on the Status of Women (Maloney 1987), the Ontario Fair Tax Commission (1993) and Status of Women Canada (Young 2000) brought a new dimension by examining the role of tax concessions in reproducing gender inequality. The new research in this book builds on this strong tradition of research, policy analysis and reform on gender in the tax-transfer system.

\section{Australia's tax-transfer system}

This part briefly explains the tax and expenditure context of policy affecting women and the key concepts and structure of Australia's taxtransfer system. The tax-transfer system and the systems for funding child care and retirement policy are almost exclusively the responsibility of the federal government. ${ }^{6}$

5 This hefty and exciting type-written photocopied report was provided to Miranda Stewart in 1991 by tax professor Richard Vann, who had obtained it from the author, in a direct transfer of policy ideas across countries.

6 However, the detailed policy, design and delivery of many education, child care and other policies is carried out at the state and territory level or through intergovernmental processes in National Partnership Agreements and the Council of Australian Governments. 
The federal tax system, illustrated in Figure 1.1, raises about 80 per cent of tax revenue in Australia. The federal income tax is by far the most important tax in Australia; the second largest tax is the goods and services $\operatorname{tax}(\mathrm{GST})$.

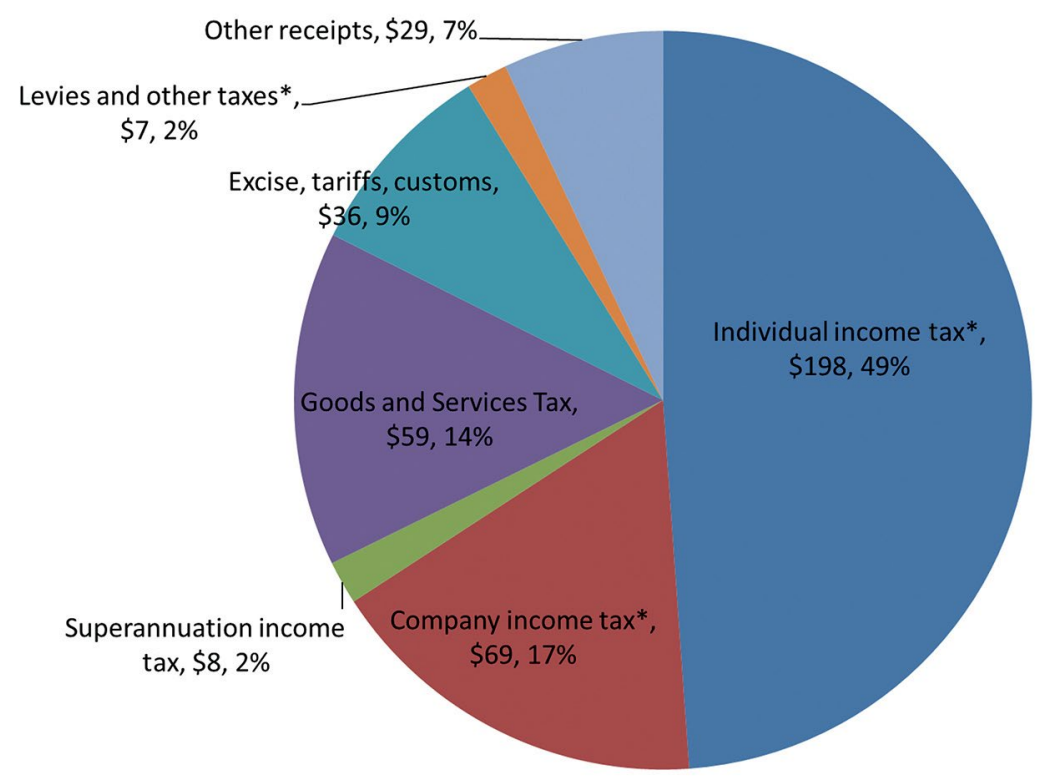

Figure 1.1: Commonwealth taxes, 2016-17 (\$billion and percentage)

* Individual income tax includes the Medicare Levy and Fringe Benefits Tax; Company income tax includes Petroleum Resource Rent Tax; Levies and other taxes includes wine equalisation tax, luxury car tax, agricultural levies and other taxes.

Source: Australian Budget 2017-18, Budget Paper 1, Budget Statement 5, Table 9 (chart prepared by author).

\section{The income tax}

The federal income tax affects most people over the life course, directly as wage earners, business owners, homeowners, investors and retirees, or indirectly, in households as spouses or dependants. The individual income tax raised $\$ 198$ billion in 2016-17, being 49 per cent of total federal revenues (including non-tax revenues). Individual income tax revenues include the Medicare Levy, currently 2 per cent, applied on taxable income of most taxpayers above a low threshold. The Turnbull Government proposes to increase the Medicare Levy to 2.5 per cent effective 
1 July 2018, raising an additional $\$ 4$ billion each year (Treasury 2017). As shown in Figure 1.1, the individual, company and superannuation income taxes combined raised three-quarters of federal revenues.

The institutional framework for individual income tax supports collection of income-contingent government tertiary education loans, provided under the Higher Education Contribution Scheme-Higher Education Loan Program (HECS-HELP). HECS-HELP loans are not counted as taxes but are an asset on the government's books, estimated at $\$ 44.7$ billion at 30 June 2017 (Treasury 2017, Budget Paper 1, p. 7-20). These income-contingent loans are repaid by applying a surcharge on the income tax on a base of modified taxable income, so that they operate in effect as an increased tax rate for the individuals affected. This regime is discussed in Chapter 8.

Individual income tax is also a foundation of the retirement superannuation system because it is the vehicle for very substantial tax concessions for private retirement saving in superannuation funds. Tax concessions include a deduction for compulsory work-related contributions, the 'Super Guarantee' scheme, and for voluntary contributions to superannuation funds. These contributions and earnings are taxed at a low flat rate of 15 per cent (or sometimes lower) in the superannuation fund. Payouts on retirement, whether in a lump sum or pension stream, are tax-exempt. These concessions are among the largest tax expenditures reported by the Treasury, as discussed in Chapter 10 (and see Ingles and Stewart 2017a).

\section{The transfer (social security) system}

The largest and most important federal government function is social security and welfare, totalling $\$ 156$ billion in 2016-17, and comprising more than one-third of federal expenditure, as shown in Figure 1.2. This function comprises mainly cash payments or 'transfers' by the government to individuals and families; it also includes expenditure on aged care and contributions to disability, veterans and child care services. Social security expenditure categories are summarised in Table 1.2 and the relative size of different payments is indicated in Figure 1.3. State and territory governments have primary responsibility for government spending on public goods such as child care centres, hospitals and schools, although the Commonwealth government contributes about half of the cost of those functions in direct spending and by grants to the states. 


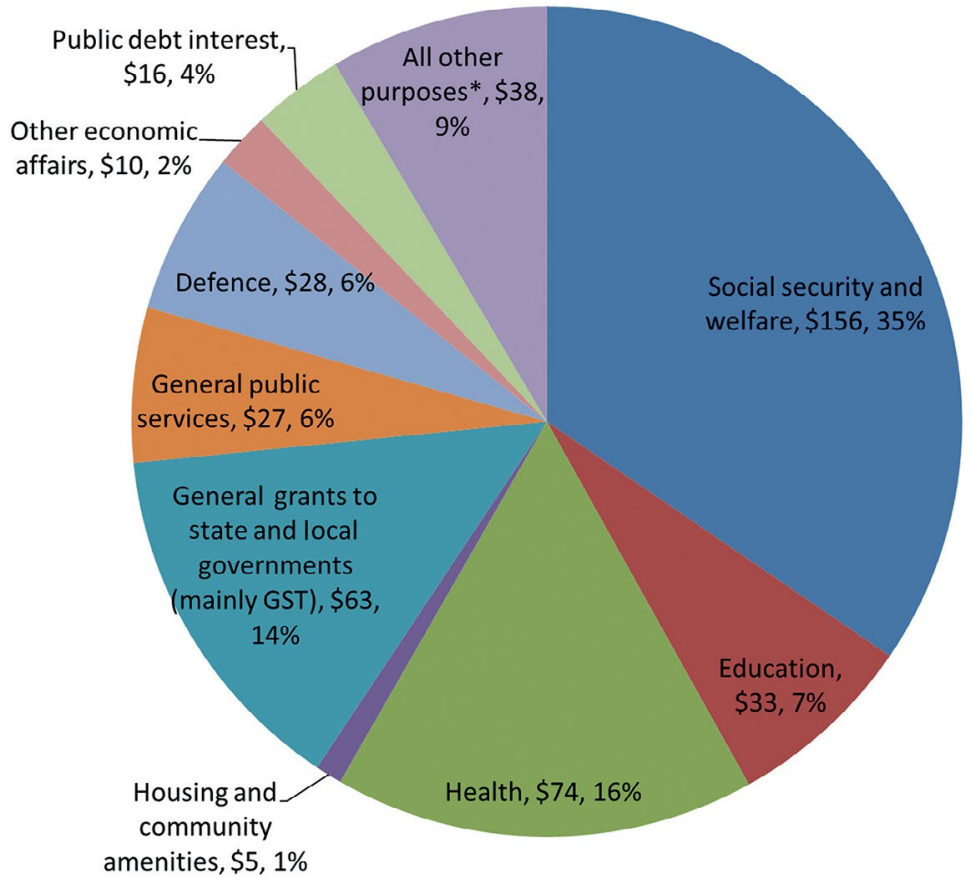

Figure 1.2: Commonwealth expenditures, 2016-17 (\$billion and percentage)

* All other purposes includes expenditure categories of public order and safety; recreation and culture; fuel and energy; mining, manufacturing and construction; transport and communication; and other purposes excluding general intergovernmental revenue assistance and public debt interest.

Source: Australian Budget 2017-18, Budget Paper 1, Budget Statement 6, Table 3 and other relevant tables (chart prepared by author).

The transfer system is targeted by means tests and applies on the basis of need. Australia has the most tightly targeted transfer system in the Organisation for Economic Co-operation and Development (OECD); it also has relatively low spending on cash transfers compared to other OECD countries (Whiteford 2017). Nonetheless, it touches the majority of Australians at some point during the life course, through payment of child care and family benefits, unemployment benefits and youth allowance, rent assistance, bereavement allowances, veteran's, disability and age pensions and supported care facilities and services. 
TAX, SOCIAL POLICY AND GENDER

Table 1.2: Social security and welfare expenditure, 2016-17 (\$billion)

\begin{tabular}{|l|c|}
\hline Payment & \$billion \\
\hline Aged pension & $\$ 44.755$ \\
\hline Aged care & $\$ 16.010$ \\
\hline Family benefits & $\$ 24.495$ \\
\hline Child care & $\$ 7.561$ \\
\hline Paid parental leave & $\$ 2.169$ \\
\hline Child support scheme & $\$ 2.041$ \\
\hline Veterans pension and care & $\$ 6.575$ \\
\hline Disability payments & $\$ 16.421$ \\
\hline NDIS and other disability & $\$ 7.169$ \\
\hline Carers & $\$ 8.132$ \\
\hline Unemployed and sick & $\$ 10.994$ \\
\hline Indigenous & $\$ 2.210$ \\
\hline Other & $\$ 3.287$ \\
\hline Administration & $\$ 3.879$ \\
\hline TOTAL & $\$ 155.698$ \\
\hline
\end{tabular}

Source: Treasury (2017, Budget Paper 1, Statement 6, Table 9 and related tables, data extracted by author).

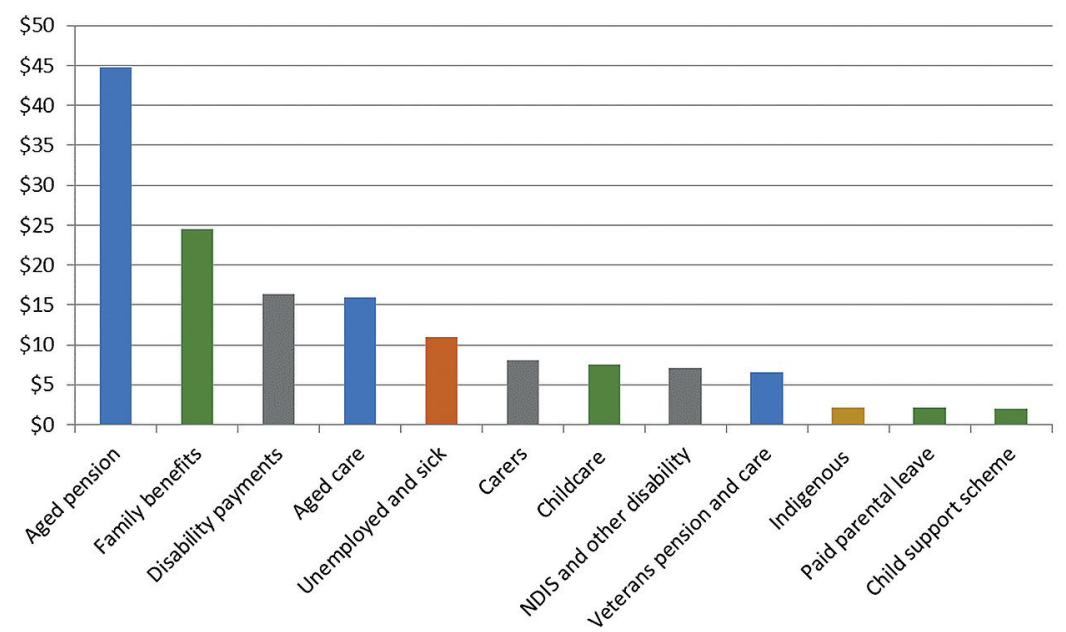

Figure 1.3: Main social security and welfare payments, 2016-17 (\$billion) Source: Treasury (2017, Budget Paper 1, Statement 6, Table 9 and related tables; chart prepared by author). 


\section{The tax-transfer unit, tax rates and means testing}

Australian tax and social security laws today are drafted to be almost entirely 'gender-neutral'. Most formally discriminatory or genderspecific provisions have been eliminated from the statute books and administrative processes. Some of these changes have only just taken effect because of long policy transitions. For example, the eligibility age for the age pension used to be lower for women (60) than for men (65). Women born in 1949 and later will now qualify at age 65, as do men. The already-enacted policy to increase the eligibility age to 67 years is being phased in equally for women and men. Formal equality has also been achieved for same-sex couples, albeit not as married couples but instead as equal to de facto opposite-sex couples. Since 2009, all tax, superannuation and welfare laws recognise same-sex couples as 'domestic partners' (like opposite-sex de facto couples) and also recognise the children of those couples on an equal basis. In Australia, unlike some other countries including the US and Germany, formal status as 'married' is not required for equal treatment of couples in these laws.

However, some elements of the tax-transfer system affect individuals and families in a way that is, in substance and effect, discriminatory against women. On the other hand, important features of the tax-transfer system, such as the needs-based age pension, benefit many women who would otherwise live in poverty and who do not have sufficient retirement savings.

Key features of the tax-transfer system affecting gender include the unit of assessment, tax rates and means testing. The income tax applies to the individual as the tax unit, levying tax at progressive rates that rise as taxable income rises. However, most benefits in the transfer system are means tested on joint, or couple, income.

Tax rates for the 2016-17 tax year are in Table 1.3, and the basic structure of the marginal progressive tax rates and average tax rate is illustrated in Figure 1.4. 
Table 1.3: Income tax rates and thresholds, 2016-17

\begin{tabular}{|l|l|}
\hline Taxable income & Tax on this income \\
\hline $0-\$ 18,200$ & Nil \\
\hline$\$ 18,201-\$ 37,000$ & 19 c for each $\$ 1$ over $\$ 18,200$ \\
\hline$\$ 37,001-\$ 87,000$ & $\$ 3,572$ plus 32.5 c for each $\$ 1$ over $\$ 37,000$ \\
\hline$\$ 87,001-\$ 180,000$ & $\$ 19,822$ plus 37 c for each $\$ 1$ over $\$ 87,000$ \\
\hline$\$ 180,001$ and over & $\$ 54,232$ plus 45 c for each $\$ 1$ over $\$ 180,000$ \\
\hline
\end{tabular}

Does not include Medicare Levy (2 per cent), temporary budget repair levy (2 per cent on top marginal tax rate) or HECS-HELP repayment schedule.

Source: ATO, www.ato.gov.au.

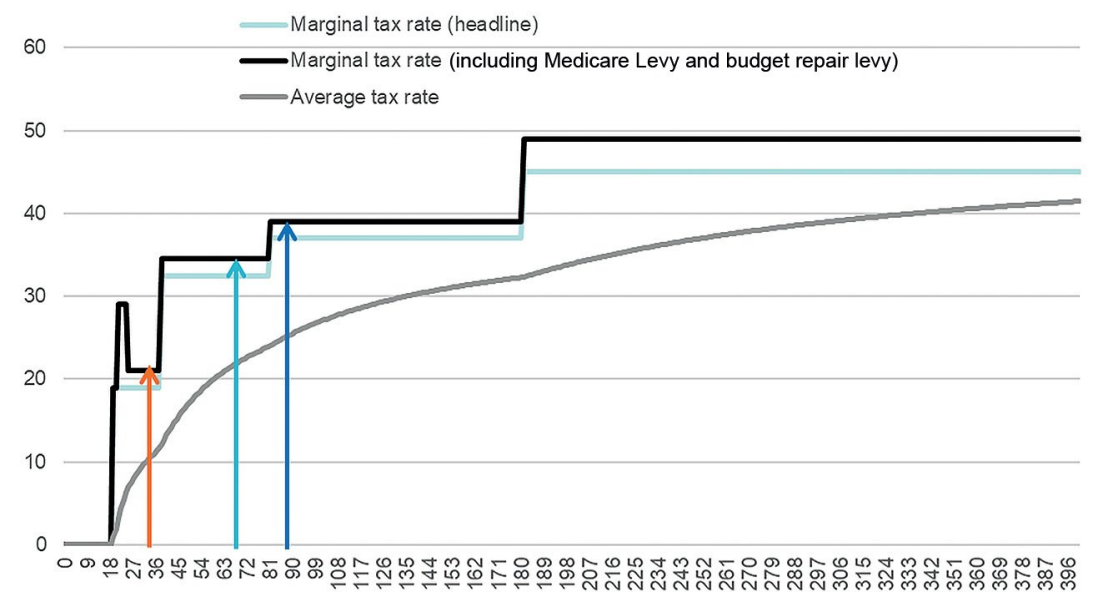

Figure 1.4: Progressive marginal and average income tax rates (\%)

The 'bump' in the black line is the phase-in of the Medicare Levy.

Source: Author; ATO, 2014-15 tax rates.

The progressive individual tax rate structure is intended to reflect the ability to pay of the taxpayer, so as to deliver what is often called vertical equity. This is illustrated in Figure 1.4. The left-hand arrow on Figure 1.4 indicates a person on the minimum wage of about $\$ 35,000$ per year, who faces a marginal tax rate (MTR) of 19 per cent plus the Medicare Levy and an average tax rate (ATR) of about 11 per cent, meaning that about 11 per cent of his or her taxable income is paid in tax. The middle arrow indicates a woman on average female full-time earnings of about $\$ 70,000$, who faces an MTR of 34.5 per cent including the Medicare Levy and an 
ATR of 22 per cent. The right-hand arrow indicates a man on average male full-time earnings of about $\$ 89,000$, who faces a MTR of 37 per cent plus the Medicare Levy.

A person in the top 10 per cent of the income distribution earns about $\$ 94,000$ (ignoring capital gains and before deductions and losses) and will face the 37 per cent MTR. A person in the top 1 per cent of the income distribution earns more than $\$ 237,341$ in a year (ignoring capital gains and before deductions and losses) and will usually face the top MTR. In Budget 2017-18, the government proposes to increase the Medicare Levy to 2.5 per cent for all taxpayers. In contrast, the ALP proposes to limit that increase to the top two tax brackets and to retain the temporary budget repair levy of 2 per cent, bringing the top marginal income tax rate to 49.5 per cent. For more on top incomes, see Chapter 9.

The tax rate structure also aims to achieve horizontal equity between taxpayers in similar circumstances (with similar taxable income). However, significant differences between taxpayers, such as the cost of children or of disability support, are largely ignored in Australia's tax system. These characteristics are instead addressed through transfer payments to families in the social security (transfer) system.

Australia's transfer means tests determine eligibility, and amount of cash benefits payable, based on income and assets. Means testing produces an effect that is equivalent to a progressive tax rate scale in reverse: the higher the income or assets, the lower the payment or benefit, which is phased out or tapered over a range of income. Where the benefit recipient is a member of a couple, or dependant child of a family, the unit of assessment is a joint unit in which the means test is based on income or assets of both members of the couple and payment rates are set on a different, joint scale intended to reflect the cost of living of the family.

For example, one important benefit for families supporting children is family tax benefit part A (FTB-A). This benefit applies at a maximum rate of $\$ 5,493.25$ per child under 12 per year (other rates apply for older children). ${ }^{7}$ It is reduced for the family's adjusted taxable income over $\$ 51,904$, at a taper rate of 20 cents per dollar of income over the threshold. This is equivalent to an MTR of 20 per cent at that threshold.

7 See Department of Social Services, www.dss.gov.au/families-and-children/benefits-payments/ family-tax-benefit (accessed 3 June 2017). 
The government proposes in Budget 2017-18 to increase this taper to 30 per cent once the family's adjusted taxable income reaches $\$ 94,316$ (Treasury 2017). That is, approximately one average male wage and the wage for one day of part-time work at the average female wage. Child care and other family benefits, unemployment, age and disability pensions are also means tested on joint income although with different thresholds and taper rates.

\section{Part 1: Frameworks for gender analysis}

Part 1 presents three conceptual approaches to the analysis of gender inequality in the tax-transfer system. Gender inequality in fiscal and economic policy cannot be separated from the broad systemic challenges that Australia (like other countries) faces in financing government in the current era, as we enter a decade of fiscal deficits. Indeed, today, as in the 1990 s, it can be argued that gender inequality remains central to discourses of fiscal austerity (Philipps 1996). Nor can we consider Australia’s fiscal policy apart from broader international economic and policy trends.

In Chapter 2, Kathleen Lahey presents an international and comparative frame of analysis. She argues that the cumulative effects of tax and social expenditure cuts of the last few decades are part of a 'taxing for growth' agenda that has its origins in the neoliberal policies of the 1980s. Combined with pre- and post-Global Financial Crisis (GFC) fiscal austerity, these have contributed to Australia moving backwards on gender equality. Lahey observes that even as Australia's level of human development has risen to second place in the most recent UN Human Development Reports, its gender inequality index ranking has fallen.

Lahey then examines the specific effects of Australia's tax-transfer system for gender equality, including income taxation of capital, the company tax, the GST and the individual income tax-transfer unit on gender equality. She compares the status of women in Australia's tax-transfer system with Canada, the US and the UK, as well as with two Nordic countries, with a view to identifying its unique fiscal choices and reform options. While Australia did not implement fiscal austerity policies to the extent of some other countries after the GFC, Lahey argues that Australia has moved in the last decade towards a tax-transfer system aimed at reducing welfare payments, enforcing workforce participation and cutting tax rates especially on capital income, and has devoted little fiscal space to 
policies that can improve the economic status of women. There has been a failure to address the impact on women of high levels of unpaid work and workplace discrimination and low levels of earnings and child care resources. Lahey outlines policy alternatives capable of producing better outcomes for women over the life course.

Australia's fiscal base and national wellbeing also faces the broad demographic challenge of the ageing population, as projected in the Intergenerational Report (Treasury 2015a). Patricia Apps, in Chapter 3, explains how gender inequality in our tax-transfer system is undermining fiscal sustainability and economic growth, while changes in the tax-transfer system are contributing to increased income inequality. Australia’s fertility rate has declined from 3.5 in the 1960s to 1.8 today. As the population ages, the ratio of working-age taxpayers to the dependant population in Australia is declining, as it is in many other developed countries. This will have a direct impact on the revenue that can be raised from all taxes, especially our most important tax, the income tax.

In contrast to the previous two years, the Turnbull Government in its 2017-18 budget has sought to raise taxes, rather than rely only on expenditure cuts to finance the deficit. However, broad-based tax reform has proved difficult in an era of contestation about the goals and distributional effects of tax reform; the government appears to have abandoned its Re:Think tax reform process initiated by its predecessor in 2014 (Treasury 2015b). Yet both the LNP and the ALP remain committed to a cap on federal tax at 23.9 per cent of gross domestic product (GDP) (once fiscal balance is reached), a tax level that will inevitably require austerity approaches to transfers and public spending more broadly. Apps shows that the tax burden is being pushed towards the middle and demonstrates how an optimal tax approach that takes the position of women seriously in tax policy regarding work and care would support a truly progressive income tax combined with public investment in child care. This would improve economic efficiency and fiscal sustainability by encouraging women to reallocate their time (as they have fewer children) from work in the home to work in the labour market.

It isimportant to remember that genderinequality in economic participation and outcomes breaches the human rights of women. In Chapter 4, Helen Hodgson and Kerrie Sadiq advocate a rights-based fiscal policy agenda. In 1975, Australia ratified the International Covenant on Economic, Social and Cultural Rights (ICESCR) and, in 1983, Australia ratified the 
Convention on the Elimination of All Forms of Discrimination Against Women (CEDAW) (albeit with some reservations). Hodgson and Sadiq draw on an approach in a recent United Nations report, Progress of the World's Women (UN 2015) to apply a human rights gender lens to four important features of Australia's tax system: the individual income tax, GST, property taxes and taxes on retirement savings. In particular, they examine the impact of tax policy on the economic and social rights of women and argue for fiscal policy to be established in a framework that takes women's human rights seriously.

\section{Part 2: Work and care}

The Turnbull Government has stated a policy goal of increasing women's workforce participation, including signing up to the G20 target of increasing participation by 25 per cent by 2025 and the Minister for Women, Senator Michaelia Cash, released a Workforce Participation strategy in June 2017 (DPMC 2017). ${ }^{8}$ Increased (market or paid) workforce participation by women has been framed as an issue of broad societal, political and budgetary concern for the nation, and is also important for women's equality, producing, as the G20 stated, a 'double dividend' for equality and the economy (Gurria 2015). However, tax-transfer policy remains conflicted on this policy goal, as discussed in several chapters in this volume.

Women's workforce participation has increased substantially since the 1970s, but is still significantly below men's. Trends in women's and men's employment are shown in Figure 1.5.

While the trend is positive, a closer examination of the data shows that we have entered an equilibrium in which women who have children work part-time, producing a family model of 1.5 earners. Indeed, the data show that the increase in women's workforce participation in Australia since the 1970s has been almost entirely in part-time work, as shown in Figure 1.6.

8 The G20 target of increasing participation by 25 per cent by 2025 may be achieved more by demographics than by policy in Australia. 


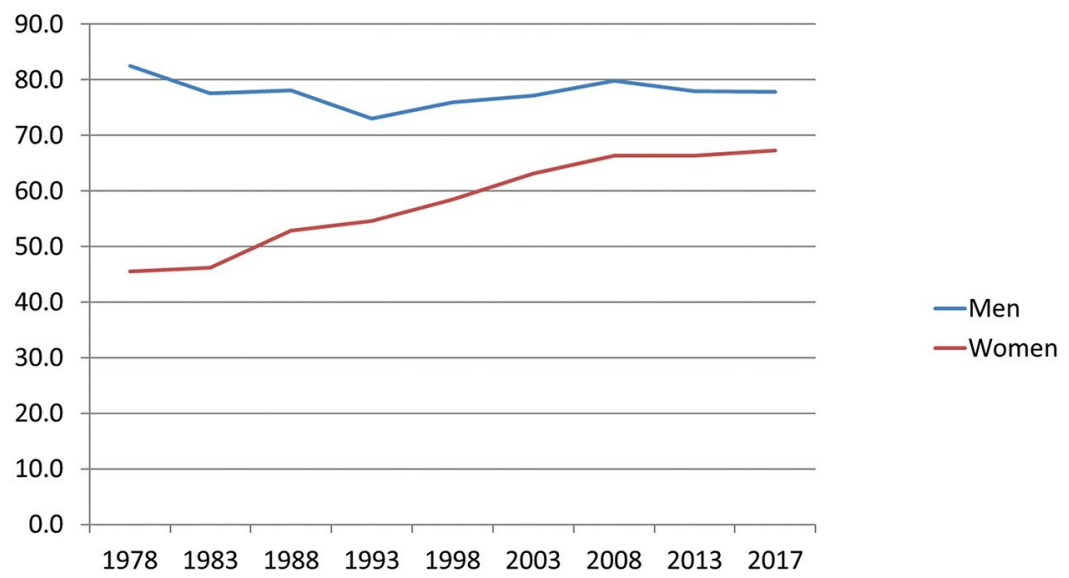

Figure 1.5: Women's and men's workforce participation, 1978-2017 (\%) Source: ABS (2017); Baird (2017).

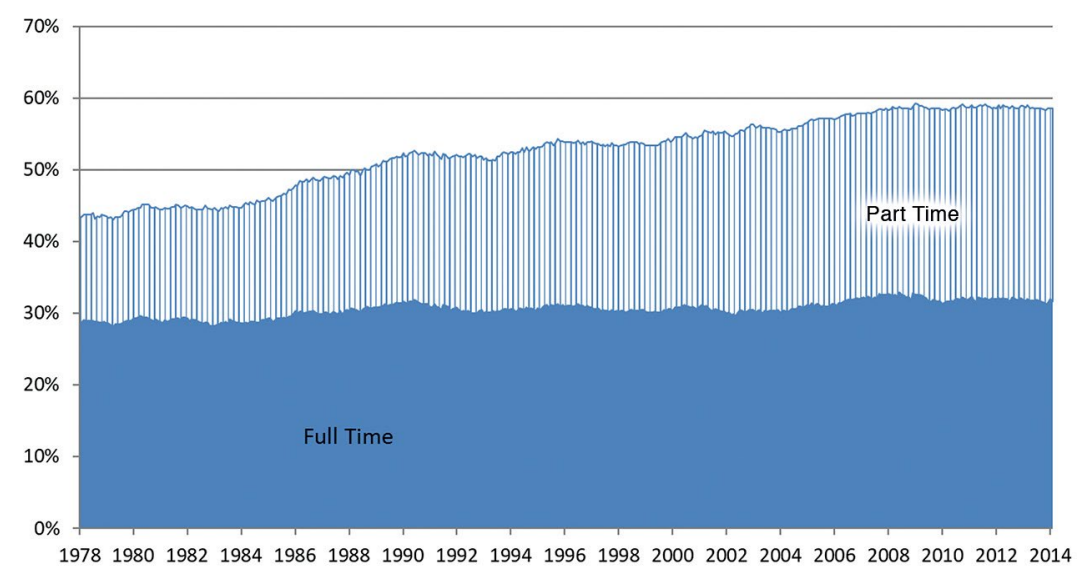

Figure 1.6: Part-time and full-time workforce participation of women, 1978-2014 (\%)

Source: Stewart et al. (2015), Chart 2.4.

We can identify a key reason for the gender gap in full-time work if we examine the participation of mothers. Workforce participation drops dramatically once a women has a child and it never fully recovers, as shown in Figure 1.7. 

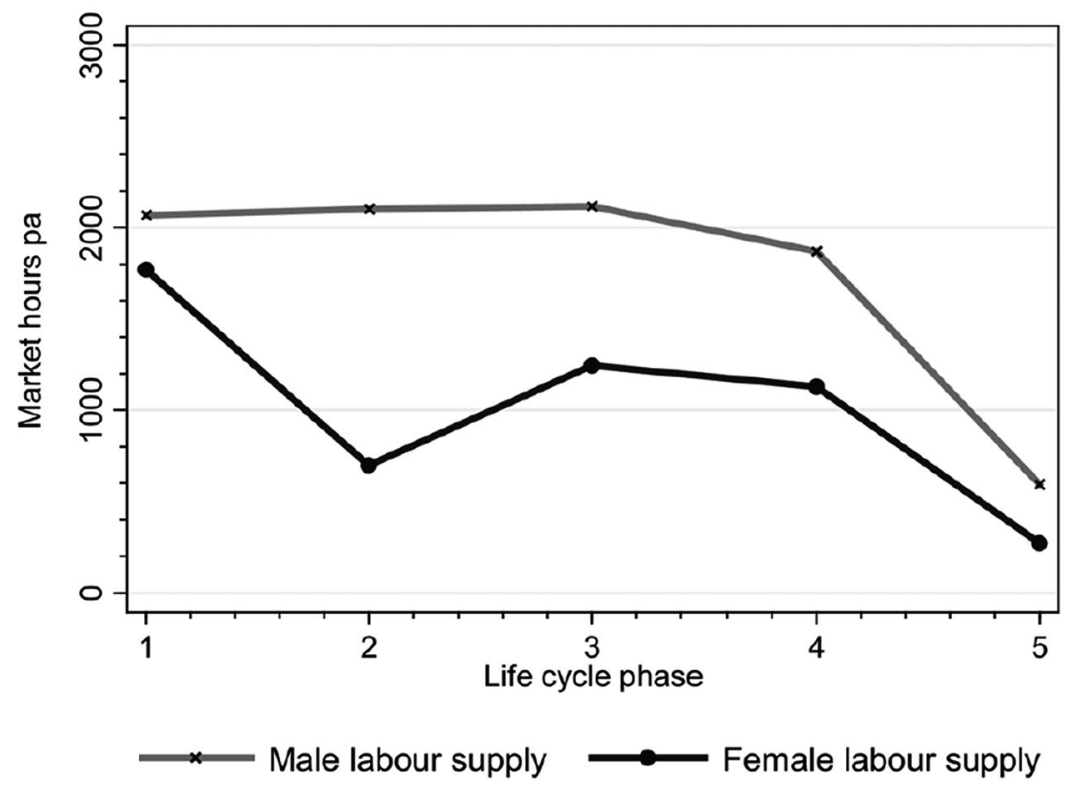

Female labour supply

Figure 1.7: Gender labour supply gap (hours worked), 2015

(1) pre-children; (2) at least one child of preschool age is present; (3) children are of school age or older but still dependant; (4) parents are of working age but with no dependant children in the household; (5) retirement age (60+ years).

Source: Apps (2015).

Guyonne Kalb (Chapter 5) examines the combined influence of taxation and expenditure policies including child care, paid parental leave and education policy on the labour supply of women taking into account that many women at some point in their life are the primary carer of a child. Many studies focus on one aspect that affects female labour supply, while there are usually many interacting influences from taxes, transfers and family policies. In addition, through the dynamic relationship of labour supply over time, early influences can have long-term impacts on labour supply, and early decisions regarding labour supply are likely to have flow-on effects on later labour supply decisions. Kalb reviews the different influences and discusses the related literature, aiming to be illustrative rather than comprehensive and showing that it is the interaction of these policies that creates inconsistencies and perverse outcomes.

Kalb explains that we can do a better job in facilitating women's labour supply. It is clear from her analysis that Australian tax-transfer policy remains incoherent and proposals for reform face constraints of apparent 
(short-term) cost to government. Consistently with Apps, it is argued by Kalb that a societal investment in increasing female labour force participation would generate long-term returns both for individual women and collectively, including reduced fiscal cost of age pensions, increased taxation revenues, productivity yields and reduced loss of human capital.

\section{Effective marginal tax rates}

A key policy setting that contributes to this result is the high effective marginal tax rates (EMTRs) produced by tight means testing of benefits in Australia's tax-transfer and child care systems. The means test for withdrawal of benefits combines with the income tax rate structure on earnings to produce the effect, referred to in many chapters in this volume, of a high EMTR on earnings. The particular effect will depend on the circumstances of the individual, family structure, wages, hours of work and cost of child care.

An example recently examined by the Productivity Commission (2015), and modified by Ingles and Plunkett (2016) is illustrated in Figures 1.8a and $1.8 \mathrm{~b}$. Figure 1.8a presents the EMTR on the earnings of a second earner (P2, usually the woman) in a low-wage household where the primary earner (P1) is earning a full-time low wage and the family have two children aged two and three in child care. The second earner begins to earn income at a low wage. For example, the line shows EMTR for the second earner at $\$ 20,000$ is about 70 per cent. This means that the family loses 70 per cent of earnings at that point in reduced benefits and increased net child care costs. Over the range from $\$ 20,000$ to $\$ 25,000$ of earnings, the EMTR on the second earner's wages exceeds 100 per cent. The coloured areas below the chart show the importance of lost benefits, net child care costs (after benefits) and tax in producing the EMTR. The ATR over the range from zero earnings to $\$ 25,000$ is about 80 per cent.

In Figure 1.8b, the same data is presented on a per day basis. It shows that for the second earner to choose to increase her part-time work from two days to four days, the 'daily' effective tax rate is between 80 to 90 per cent. The effect of EMTRs, combined with the additional costs of working, mean that many mothers derive little, if any, financial return from a return to or increase in work hours. 


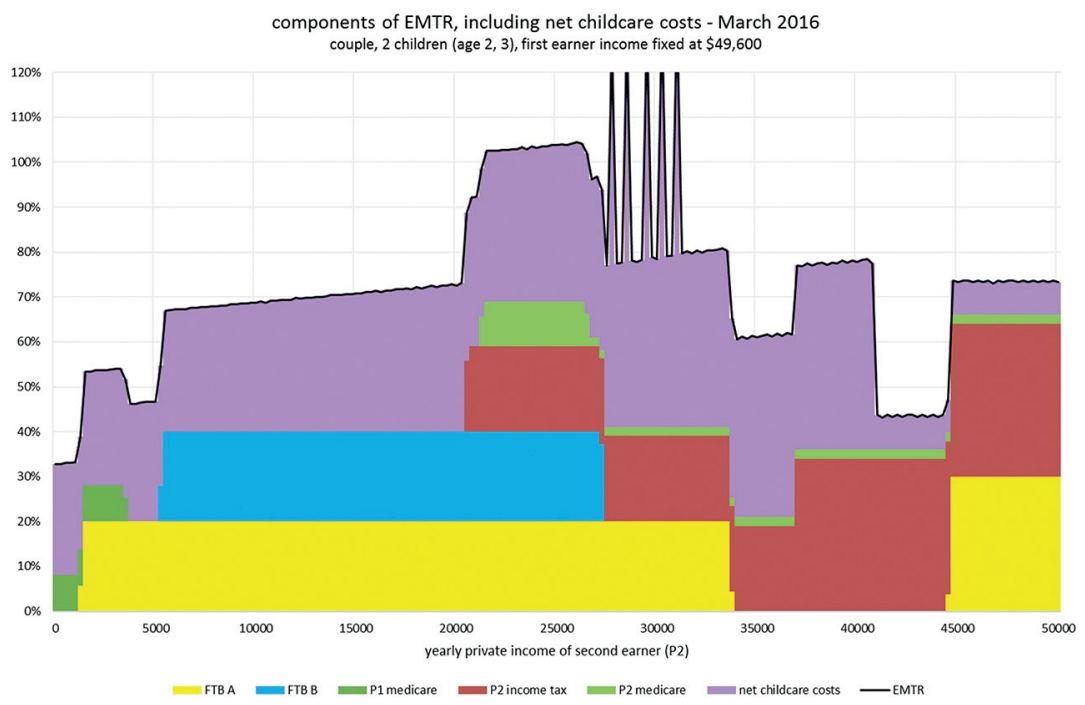

Figure 1.8a: EMTRs per $\$ 1$ of earnings, dual earner family with two children

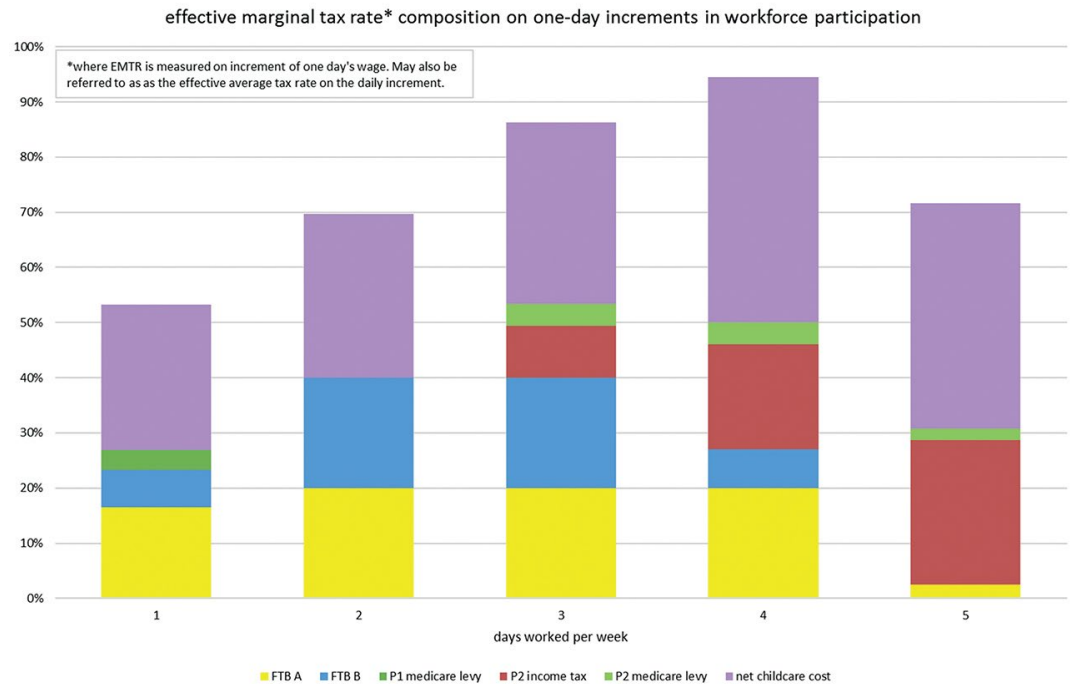

Figure 1.8b: EMTRs per day of work, dual earner family with two children Income of the primary earner is fixed at the minimum wage plus 41 per cent, full year full-time $(\$ 49,600)$. Income of second earner is minimum wage plus 20 per cent $-\$ 20.75 /$ hour (low-wage, full-time workers). This ratio is based on the ratio of men's to women's wages, full-time averages. Hours of care are $10 /$ day at $\$ 8.50 / \mathrm{hr}$. One aspect of long day care is that care is effectively charged for 10 hours in a full day, to a maximum of 50 hours per week. To mimic this, the assumption is that care hours grow faster than working hours, so that a 38-hour working week translates to 50 hours of care use. Source: Ingles and Plunkett (2016). 
The structural design of the tax-transfer system that produces the effect illustrated in Figure 1.8 is still not fully acknowledged by policymakers. Yet it is integral to women's economic disadvantage, as a result of the interaction with their position in discriminatory market and household economies. As Kalb shows, the decision not to work, or to work only a few hours per week, made on the basis of short-term financial impact because of high EMTRs, can have long-term consequences on the earning capacity of mothers over their lifetime. At the same time, it contributes to the social construction of gendered behaviour and reinforcement of gendered social norms. The Turnbull Government's new, expanded child care subsidy, to commence in 2018, will likely mitigate some of these effects, although it is still means tested and will not assist women in upper middle-income families. ${ }^{9}$

\section{The value of care}

It is important for women's and societal wellbeing that we do not focus exclusively on paid market work as the means to achieve gender equality. Julie Smith in Chapter 6 presents a 'bird's-eye view' of how gender equality in Australia has been helped or hindered in Australia's 'wage earner welfare state'. Smith focuses on the economic costs to women of their unpaid (home) reproductive and productive work, and the role of Australia's unique social protection and progressive tax regime in mitigating or exacerbating these costs. While acknowledging the importance of women's market work, Smith critiques policies aimed solely at boosting paid workforce participation. Household investments in children-such as breastfeeding and infant care-add enormously to women's and children's wellbeing and to social and economic wellbeing more broadly, as do other 'unpaid' care responsibilities (see, for example, AHRC 2013; Deloitte 2015).

Smith discusses the early financing of child endowment in Australia and the links between this policy aimed at supporting families and wage policy. Smith concludes that the evolution of Australia's social protection regime and its financing since the 1970s has been both an enemy and a friend of gender equality. A range of workforce policies that facilitate women doing caring work while not being disadvantaged in the labour market or over the life course, including in retirement, is required. Ultimately,

9 See Department of Education and Training, www.education.gov.au/child-care-subsidy-0. 
contemporary policy is failing to respond to contemporary needs for resourcing care of dependant people at the cost of both gender equity, and economic efficiency.

The design of child care policies should also take account of how child care is organised within a household. There has been a lack of debate in Australia about sharing the burden and joys of care more equally between women and men, for example through mandating parental leave for men. Huong Dinh and Maria Racionero (Chapter 7) draw on the Australian Bureau of Statistics (ABS) Time Use Survey (TUS) of 2006 to present new findings about time use of parents in balancing child care and market work. Specifically, they focus on the question: do mothers and fathers in a couple differ in the way they trade off child care time for market time? They examine time spent by mothers and fathers at home in primary (development-oriented) child care, secondary (non-developmentoriented) child care and market work. As a result of budget cuts, the ABS TUS has not been carried out since 2006, so this decade-old data is our only insight into Australian care and work time use at present.

Dinh and Racionero confirm previous findings that mothers prioritise child care time significantly more than fathers, who put more emphasis on work time. They find that mothers and fathers adjust their child care time differently based on which partner (father or mother) changes their time in market work, the type of child care and the age of the youngest child. When there is a preschool-aged youngest child, mothers prioritise primary (developmental) child care over secondary child care and over paid work. By contrast, in the same situation, fathers appear to prioritise secondary over primary child care. As time is a scarce resource and child care may have different qualities depending on the kind of care and age of children, parents cooperate to mitigate the loss in combined child care time in response to more market work time, but there are nuances in decisions that women and men make about care when they or their partners are choosing to increase market work.

\section{Lone parents at the intersection of work and care}

Several authors in this volume, including Lahey, Kalb and Smith, discuss the position of lone parents in the tax-transfer system. The tensions in Australia's tax-transfer policies for work and care are most evident in the case of lone parents, more than 85 per cent of whom are women. Families with a lone parent form about 20 per cent of families with a child 
under the age of 15 in Australia (Whiteford 2016). Even in today's era of blended families or 'shared care', it is common for children to be cared for by a primary carer in one household, while some parents are single by choice or necessity; moreover, violence against women and children is a key reason for sole parenthood.

In the 1970s, the introduction for the first time of sole parent pensions enabled a woman to look after children alone, by providing an income. Since the 1980s, the activation policy for workforce participation and increased conditionality and means testing of benefits began to push lone parents into the labour market. Increased benefits for families with children during the 1990s benefited lone parents.

Today, a more stringent work and study policy applies for lone parents. About half of lone parents receiving benefits do paid work or study at least part-time. Many lone parents are better off as a result of doing paid work and the system is designed to provide benefits while encouraging work. However, as illustrated in Ingles and Stewart (2017b), lone parents still face very high EMTRs if they seek to increase their work hours from parttime to full-time, taking account of net child care costs, except for the few who are able to obtain a high-wage full-time job. Those lone parents who are unable to work, and their children, have been made significantly worse off since 2014, when a policy shift moved lone parents off the pension payment scale onto the lower rate Newstart allowance once the youngest child in the household turns eight (Phillips and Joseph 2016). This policy has increased income inequality among lone parents, while those lone parent families who are dependant on benefits are among the poorest in the country (Whiteford 2016; Phillips and Gray 2017).

\section{Part 3: Human capital, savings and retirement}

In Chapters 8, 9 and 10, different aspects of investment in human capital, savings and retirement policy are discussed. Turning to the experience of women investing in higher education, Mathias Sinning (Chapter 8) uses the Household, Income and Labour Dynamics of Australia (HILDA) Survey for the period 2001 to 2014 to present a new analysis of the private returns to higher education for women and men. The human capital literature assumes that tertiary (post-school) education is an investment in human capital producing both private and public returns, and general 
results show that highly educated people earn more. The private return is calculated by Sinning to be the earnings of individuals calculated as a present value of lifetime earnings resulting from higher education.

Sinning confirms that both men and women have higher lifetime earnings from tertiary education compared to those without such education. However, consistent with other data about the gender wage gap, Sinning finds from the HILDA data that women consistently earn lower hourly wages than men at all levels of education. Once it is taken into account that women work part-time more than men, then women's weekly earnings may be significantly lower than those of men. Women with either a postgraduate or a Bachelor or Honours degree earn about 50 per cent more over their lifetime than women with Year 12 or below; there is no earnings benefit for women of postgraduate education. Men with postgraduate education earn about 83 per cent more than men with Year 12 or below, and also earn more than men with a Bachelor or Honours degree. Most strikingly, Sinning shows that women derive no earnings benefit from technical or vocational education, in stark contrast to men.

Sinning then discusses the costs and benefits of higher education funding through HECS-HELP. He shows how gender differences in earnings have considerable implications for the repayment of income-contingent HECS-HELP debts. The current threshold for repayment of the HECSHELP debt is $\$ 54,869$, at which point a repayment rate of 4 per cent of adjusted taxable income applies (on top of income tax).

The average outstanding debt of male university graduates converges to zero over a 30-year period, whereas the average outstanding debt of female university graduates remains positive. Many female university graduates never earn enough to repay their tertiary student loans in full, both because of the gender wage gap and because of part-time and interrupted work patterns. The government proposes in Budget 2017-18 to significantly lower the HECS-HELP repayment threshold to $\$ 42,000$, and to introduce a sliding scale of repayment rate from 1 per cent of adjusted taxable income up to 4 per cent at the current threshold. As noted by the National Federation for Australian Women (NFAW 2017), this will cause many new graduates to repay loans sooner. For women who are working part-time while caring for children, or who are working on relatively low wages, it will push up both the EMTR and ATR that they pay, reducing further the after-tax return to work. 
In Chapter 9, Miranda Stewart, Sarah Voitchovsky and Roger Wilkins present novel findings about women with top incomes. A gender analysis of the top income groups in Australia is possible because of the ability to obtain customised individual income tax statistics from the Australian Taxation Office (ATO). Building on the global movement of 'top incomes' research, ${ }^{10}$ Chapter 9 presents the share of women in the top 10 per cent, 5 per cent, 1 per cent and 0.1 per cent in the income distribution. It compares patterns of top income women in Australia with other countries, as well as providing some possible explanations for the Australian trends.

As in other countries, Australia has experienced sustained increases in the income shares of top income groups since the early 1980s, and this is explained largely by reductions in top tax rates. Overall, the income share of the top 1 per cent has nearly doubled from just over 4 per cent in $1982-83$ to just over 8 per cent in 2013-14. The income share of the top 5-10 per cent (91st to 95th percentiles) declined slightly to 2008-09, since when it has risen rapidly. Stewart, Voitchovsky and Wilkins find that in 2013-14, women account for one-quarter of the top 10 per cent. Higher up the income distribution, the proportion is lower, but women still comprise 17 per cent of the top 0.1 per cent. When compared to other countries including Spain, Denmark, Canada, New Zealand, Italy, the UK and Norway, Australia has a relatively low share of women in the top 10 per cent but a larger cohort of women in the top 1 per cent and 0.1 per cent. A significant proportion of women with top incomes derive income from savings and investment sources, rather than from high wages.

One possible explanation for the Australian results is the age profile of women with top incomes. Another possible explanation is tax planning by couples with top incomes. In all individual income tax systems that have a progressive rate structure, there is a structural incentive for related parties - especially family members - to split income so as to reduce the overall tax burden. In Australia, the legal structure and interpretation of the income tax has long facilitated certain kinds of income splitting. As explained by Apps (Chapter 4), the joint income-tested family benefits produce a 'quasi-joint tax unit' for many families with children. It is less well known-except to tax lawyers and the high-income individuals

10 See the World Wealth and Income database at: wid.world/. 
and families who they advise- that a 'quasi-joint' tax unit can also be produced by splitting income among the 'professional and commercial classes'. ${ }^{11}$ The trends presented in Chapter 9 are consistent with anecdotal evidence of family income splitting as a common practice among those with high incomes, enabling them to pay less tax, and undermines the overall tax base.

\section{Gender and the retirement system}

Many chapters in this volume, including Apps (Chapter 2) and Smith (Chapter 6) discuss the retirement savings system and the age pension, in relation to the impact for women who are economically disadvantaged over the life course. The age pension, which is not linked to savings accrued during paid work, operates as life course remuneration for many women who do unpaid care work or have interrupted working lives, as well as providing necessary income support where no private provision is available. The shift from the age pension, which was neutral between paid and unpaid work, to reliance on a second pillar of occupational superannuation has magnified gender inequalities in retirement income. Siobhan Austen and Rhonda Sharp in Chapter 10 present a detailed gender impact analysis to assess the sufficiency of the funding available for the retirement incomes of older Australian women. They do this by examining inputs (superannuation saving subject to tax concessions) and outputs from the retirement system (payments and incomes). They critique the supposed 'link' between the input tax concessions and the output retirement incomes as being weak in a number of respects. They conclude that current policies are producing especially poor outcomes for Australian women, with women experiencing higher levels of poverty and lower levels of wealth as they age.

Austen and Sharp argue for the importance of policy analysis at the individual level, so as to identify the gender impact of retirement and pension policy. Household analysis is often favoured in retirement incomes policy because of a view that wealth is distributed in family units. Austen and Sharp observe that maldistribution of the ownership and control of resources within households exposes individuals within the household (more often women than men) to the risks of poor decision-making and

11 As illustrated in judicial decisions such as FCT $v$ Everett (1980) 143 CLR 440 at 457 per Murphy J. 
inadequate resources. In any event, fully half of Australian women are single by age 75 , meaning that the single unit analysis is appropriate. In the result, Austen and Sharp, as do several other contributors, argue for retaining the age pension as the first pillar of the retirement income system for women.

\section{Part 4: Towards gender equality in the tax- transfer system}

After decades of advocacy and policy change, gender equality remains unfinished business in Australian economic and fiscal policy. The taxtransfer system, intersecting with child care, parental leave, education, work and retirement policies, reproduces deeply gendered dynamics that disadvantage women in spite of political commitments to gender equality. Since the move of the Office for Women back into the Department of Prime Minister and Cabinet in 2013, there have been some developments in mainstreaming policy to achieve gender equality, although greater direction and leadership is needed. Government support for gender policy analysis has been lacking and both Labor and LNP governments, pursing governmental budget 'efficiencies', have dismantled policy and data capability for addressing gender inequality over the last few years.

In the final Chapter 11, Meredith Edwards and Miranda Stewart explore the policy and process of achieving gender equality in these core policy fields. They explore how to engage gender analysis, evaluation and research insights into policy processes to improve outcomes for women and Australian society as a whole. Australian tax-transfer policy seems to be in transition towards a new regime of care and work, in which women are increasingly engaged in the paid workforce. These issues are hotly debated but there is a real risk that the gender equality implications of new policies will not be fully acknowledged, in particular in an environment of fiscal constraint, so that new policies will continue to assume explicitly or implicitly that care work will continue to be done outside the market, or at a low market cost, mostly by women.

There is, today, a new global impetus to incorporate gender impact analysis into government budgeting (for example, see OECD 2016). Governments have a significant opportunity to reform policy in the tax-transfer system, child care and retirement fields as a lever to redress the disadvantages faced by women across the life course relative to men. Reforms to support 
gender equality can produce increased economic security and wellbeing for women and for the economy and population as a whole in the short and long term.

\section{References}

ABS (Australian Bureau of Statistics). 2016. Gender IndicatorsAustralia-August 2016. Publication 4125.0. Available at: www.abs. gov.au/ausstats/abs@.nsf/mf/4125.0 (accessed 2 March 2016).

ABS. 2017. Labour Force, Australia, Detailed-Electronic Deliver. Cat. no. 6291.0.55.001.

AHRC (Australian Human Rights Commission). 2013. Investing in care: Recognising and valuing those who care, Volume 1: Research Report. Sydney: Australian Human Rights Commission.

Apps, Patricia. 1981. A Theory of Inequality and Taxation. Cambridge: Cambridge University Press.

Apps, Patricia. 2015. 'The central role of a well-designed income tax in "the modern economy". Australian Tax Forum 30(4): 845-863. doi. org/10.2139/ssrn.2662280

Asprey, Ken (Chair). 1975. Full Report 31 January 1975. Taxation Review Committee (the 'Asprey Committee'). Canberra: Australian Government Publishing Service.

Baird, Marian. 2017. Presentation to International Association of Women Judges' Asia Pacific Regional Conference, 27-28 April 2017, Sydney. Available at: dcconferences.eventsair.com/QuickEventWebsitePortal/ iawj2017/cs/Agenda

Baldock, Cora V. and Bettina Cass (eds). 1983. Women, social welfare and the state in Australia. Sydney: George Allen \& Unwin.

Deloitte. 2015. The economic value of informal care in Australia in 2015. Report for Carers Australia. Deloitte Access Economics.

Department of Education and Training. 2017. Universal Access to Early Childhood Education: National Partnership Agreements. Available at: www.education.gov.au/national-partnership-agreements 
DPMC (Department of Prime Minister and Cabinet). 2017. Towards 2025: An Australian Government Strategy to Boost Women's Workforce Participation. Available at: womensworkforceparticipation.pmc.gov.au/

Edwards, Meredith. 1981. Financial Arrangements within Families. Canberra: National Women's Advisory Council.

Grattan, Michelle. 2016. 'Turnbull finds it easy to declare himself a feminist'. The Conversation, 6 June. Available at: theconversation. $\mathrm{com} /$ turnbull-finds-it-easy-to-declare-himself-a-feminist-60574

Graycar, Regina and Jenny Morgan. 1990. The Hidden Gender of Law. Leichhardt: Federation Press.

Grbich, Judith. 1987. 'The Position of Women in Family Dealing: The Australian Case'. International Journal of the Sociology of Law 15(3): 309-316.

Gurria, Angel. 2015. 'Bringing gender equality to the core of the G20 agenda'. OECD.org. Available at: www.oecd.org/g20/topics/ employment-and-social-policy/bringing-gender-equality-to-the-coreof-the-g20-agenda.htm

Harris Rimmer, Susan and Marian Sawer. 2016. 'Neoliberalism and gender equality policy in Australia'. Australian Journal of Political Science 51(4): 742-758. doi.org/10.1080/10361146.2016.1222602

Henderson, Ron. 1975. Commission of Inquiry into Poverty. Canberra: Australian Government Publishing Service.

Ingles, David and David Plunkett. 2016. Effective Marginal Tax Rates. TTPI Policy Brief 1/2016. Available at: taxpolicy.crawford.anu.edu. au/publication/9083/effective-marginal-tax-rates

Ingles, David and Miranda Stewart. 2017a. 'Reforming Australia's Superannuation Tax System and the Age Pension to Improve Work and Savings Incentives'. Asia \& the Pacific Policy Studies 4(3): 417436. DOI: $10.1002 /$ app 5.184

Ingles, David and Miranda Stewart. 2017b. 'Does It Pay To Work? The Case of a Single Parent with 4 Children'. Austaxpolicy: Tax and Transfer Policy Blog, 24 January. Available at: www.austaxpolicy.com/pay-workcase-single-parent-4-children/ 
Keens, Carol and Bettina Cass. 1982. Welfare: Some Aspects of Australian tax policy: Class and Gender Considerations. NSW: Social Policy Research Centre, University of NSW.

Lahey, Kathleen and M. Eaton. 1988. The Taxation of Women in Canada: A Research Report. Canada: Queen's University.

Leslie, Tim. 2014. 'Winners and Losers of the 2014 Budget'. ABC News, 13 May. Available at: www.abc.net.au/news/2014-05-13/budgetwinners-and-losers/5433178

Lister, Ruth. 1992. Women's Economic Dependency and Social Security. Research Discussion Series no. 2. Manchester: Equal Opportunities Commission.

Maloney, Maureen. 1987. Women and Income Tax Reform. Background paper prepared for the Canadian Advisory Council on the Status of Women. Ottawa: Canadian Advisory Council on the Status of Women.

NFAW (National Foundation for Australian Women). 2017. Gender Lens on the Budget 2017. Available at: www.nfaw.org/gender-lens-on-thebudget/

OECD (Organisation for Economic Co-operation and Development). 2016. Gender Budgeting in OECD Countries. Public Governance and Territorial Development Directorate, 37th Annual Meeting of OECD Senior Budget Officials, Stockholm, 9-10 June.

Ontario Fair Tax Commission. 1993. Fair Taxation in a Changing World: Report of the Ontario Fair Tax Commission. Toronto, Canada: University of Toronto Press.

Philipps, Lisa. 1996. 'Discursive Deficits: A Feminist Perspective on the Power of Technical Knowledge in Fiscal Law and Policy'. Canadian Journal of Law and Society 11(1): 141-176.

Phillips, Ben and Matt Gray. 2017. Distributional Modelling of the Australian Tax and Social Security System Changes: 2005-2015 and beyond. Available at: csrm.cass.anu.edu.au/research/publications/ distributional-modelling-australian-tax-and-social-security-systemchanges 
Phillips, Ben and Cukkoo Joseph. 2016. Income Trends for Selected Single Parent Families. ANU Centre for Social Research and Methods. Available at: rsss.anu.edu.au/sites/default/files/Cameo\%20 analysis $\% 20 \mathrm{of} \% 20$ single $\% 20$ parents.pdf

Productivity Commission. 2015. Childcare and Early Childhood Learning Final Report. Available at: www.pc.gov.au/inquiries/completed/child care\#report

Pugh, Cedric. 1983. 'Review of $A$ Theory of Inequality and Taxation'. Journal of Economic Issues 17(3): 826-830. doi.org/10.1080/002136 24.1983.11504165

Senate Economic References Committee. 2016. 'A husband is not a retirement plan': Achieving economic security for women in retirement. Report, 29 April. Commonwealth of Australia. Available at: www. aph.gov.au/Parliamentary_Business/Committees/Senate/Economics/ Economic_security_for_women_in_retirement/Report

Shaver, Sheila. 1989. 'Gender, Class and the Welfare State: The Case of Income Security in Australia'. Feminist Review 32(Summer): 90-110. doi.org/10.1057/fr.1989.21

Shorten, Bill. 2016. Budget Reply Speech. 3 May. Available at: www.alp. org.au/bill_shorten_budget_reply_2016

Stewart, Miranda, Moore Andre, Whiteford Peter and Grafton Quentin. 2015. A Stocktake of the Tax System and Directions for Reform: Five years after the Henry review. Report, Tax and Transfer Policy Institute. Available at: taxpolicy.crawford.anu.edu.au/files/uploads/taxstudies_ crawford_anu_edu_au/2015-03/stocktake_report_final_web_ version.pdf

Treasury. 2015a. Intergenerational Report: Australia in 2055. Canberra: Commonwealth of Australia. Available at: treasury.gov.au/ publication/2015-intergenerational-report/

Treasury. 2015b. Re:Think Discussion Paper. Australian Government. Available at: bettertax.gov.au/files/2015/03/TWP_combined-online. pdf

Treasury. 2017. Budget 2017-18. Available at: www.budget.gov.au 
UN (United Nations). 2015. Progress of the World's Women 2015-2016: Transforming Economics, Realizing Rights. Available at: progress. unwomen.org

WGEA (Workplace Gender Equality Agency). 2016. Gender Pay Equity Insights -2016 Report. Available at: www.wgea.gov.au/sites/default/ files/BCEC_WGEA_Gender_Pay_Equity_Insights_2016_Report.pdf

Whiteford, Peter. 2016. 'Ideas for Australia: Welfare reform needs to be about improving well-being, not punishing the poor'. The Conversation, 21 April. Available at: theconversation.com/ideas-for-australia-welfarereform-needs-to-be-about-improving-well-being-not-punishing-thepoor- 56355

Whiteford, Peter. 2017. Social security and welfare spending in Australia: Assessing long-term trends. TTPI Policy Brief 1/2017. Available at: taxpolicy.crawford.anu.edu.au/publication/10880/social-securityand-welfare-spending-australia-assessing-long-term-trends

Williams, Blair and Marian Sawer. Forthcoming. 'Rainbow Labor and a purple policy launch: Gender and Sexuality Issues'. In Anika Gauja, Peter Chen, Jennifer Curtin and Juliet Pietsch (eds), Double Disillusion' The 2016 Australian Federal Election. Canberra: ANU Press.

Young, Claire. 2000. Women, Tax and Social programs: The Gendered Impact of Funding Social Programs Through the Tax System. Report for Status of Women Canada. 
This text is taken from Tax, Social Policy and Gender: Rethinking equality and efficiency, edited by Miranda Stewart, published 2017 by ANU Press, The Australian National University, Canberra, Australia.

dx.doi.org/10.22459/TSPG.11.2017.01 